\title{
Power-frequency balance with superconducting magnetic energy storage using optimized intelligent controller
}

\section{Y. K. Bhateshvar,}

\section{H. D. Mathur}

Electrical and Electronics Engineering Department, BITS, Pilani (India)

E-mail:yogeshbhateshvar@gmail.com; mathurhd@gmail.com
This paper presents an optimized design of the fuzzy logic controller (FLC) for the two-area interconnected power system to regulate the frequency deviation and power deviations when subjected to change in load. The developed power system model apart from having conventional sources also has a superconducting magnetic energy storage (SMES) unit which is capable of storing electric energy and releases it as per system requirements. SMES is used to support short-term active power in order to maintain power-frequency balance in the system under test. This two-area power system considered comprises reheat thermal and hydro units of the same capacity in each area. In the proposed control scheme, optimization of the FLC is carried out in four different steps: the first step is for optimization of the range of input and output variables, the second one for membership functions, the third and fourth steps for rule base and rule weight optimization, respectively. Genetic algorithm (GA) is used for the proposed step-by-step optimization process. Comparing the other methods available in literature, the proposed method is found more effective in achieving optimal results. Simulation results are also tabulated as a comparative performance in view of the main performance indices, i. e. settling time and peak undershoot.

Key words: multi-area power system, load frequency control, fuzzy logic controller, genetic algorithm, SMES

\section{INTRODUCTION}

The growing concern of maintaining a continuous balance between generation and load is pushing power engineers to evolve advance control strategies for effectively minimizing deviations. Load frequency control (LFC) is a system for controlling power generation as per fluctuating load demand as well as to ensure the quality of power supply mainly in terms of frequency deviation on sudden load perturbations.

Researchers have explored various techniques to address this issue, but recent technologies in the smart grid era have not received substantial attention in literature for frequency regulation problems. Smart grid technologies offer consumers quality power by means of new energy storage systems such as a SMES $[1,2]$, an ultra 
capacitor [3], etc. This paper attempts to make use of superconducting magnetic energy storage as an option to supplement sudden demand of power and support frequency deviation to a large extent. Researchers also focussed on different control techniques to execute, but intelligent controllers with SMES in multi-area systems have not been studied in detail so far. Our study aims to model a fuzzy logic based controller where various controller design stages are optimized using a genetic algorithm.

Fuzzy logic based controllers have been widely accepted for different engineering and industrial applications. FLC is an appropriate choice for linear, non-linear, complex or ill-defined systems. The fuzzy logic approach, in providing solutions for LFC, has been reported in $[4,5]$. But an optimized FLC design requires detailed practical knowledge and experience of the system under test. Therefore, to achieve better dynamic performance with the help of optimization algorithms, FLC can be tuned easily without detailed mathematical knowledge about the system. Many efforts have been made in this direction as well $[6,7]$, but still the oscillatory behaviour response issue needs to be settled.

In order to suppress oscillations in an interconnected power system, SMES plays a significant role and it also improves power system dynamic performance [8]. In an interconnected power system SMES might be connected to any of the control area or the area based on the sys- tem requirement. Apart from frequency oscillation damping, it also helps in damping tie-line power oscillations [9].

In this paper, the proposed strategy for damping oscillation in the interconnected power system focuses mainly on intelligent control with fuzzy logic and optimization with a genetic algorithm. A comprehensive comparison of results obtained with Zigler Nicholas tuned PID, GA optimized PID, partially optimized fuzzy and fully optimized fuzzy controllers is presented. In the partially optimized fuzzy control, scaling factor and membership functions are optimized while the fully optimized fuzzy control also takes care of rule base and rule weight optimization. MATLAB / Simulink is used for all simulation purposes.

\section{SYSTEM EXAMINED}

\section{Load frequency control for two-area power system}

The system examined consists of two control areas having a reheat thermal generating unit in control area-1 and a hydro generating unit in control area 2, and these two control areas are connected by a tie-line. The complete system model is shown in Fig. 1. There are two main objectives in this control problem:

(i) Each control area should supply its own load demand as far as possible and power transfer through the tie line should be on mutual agreement.

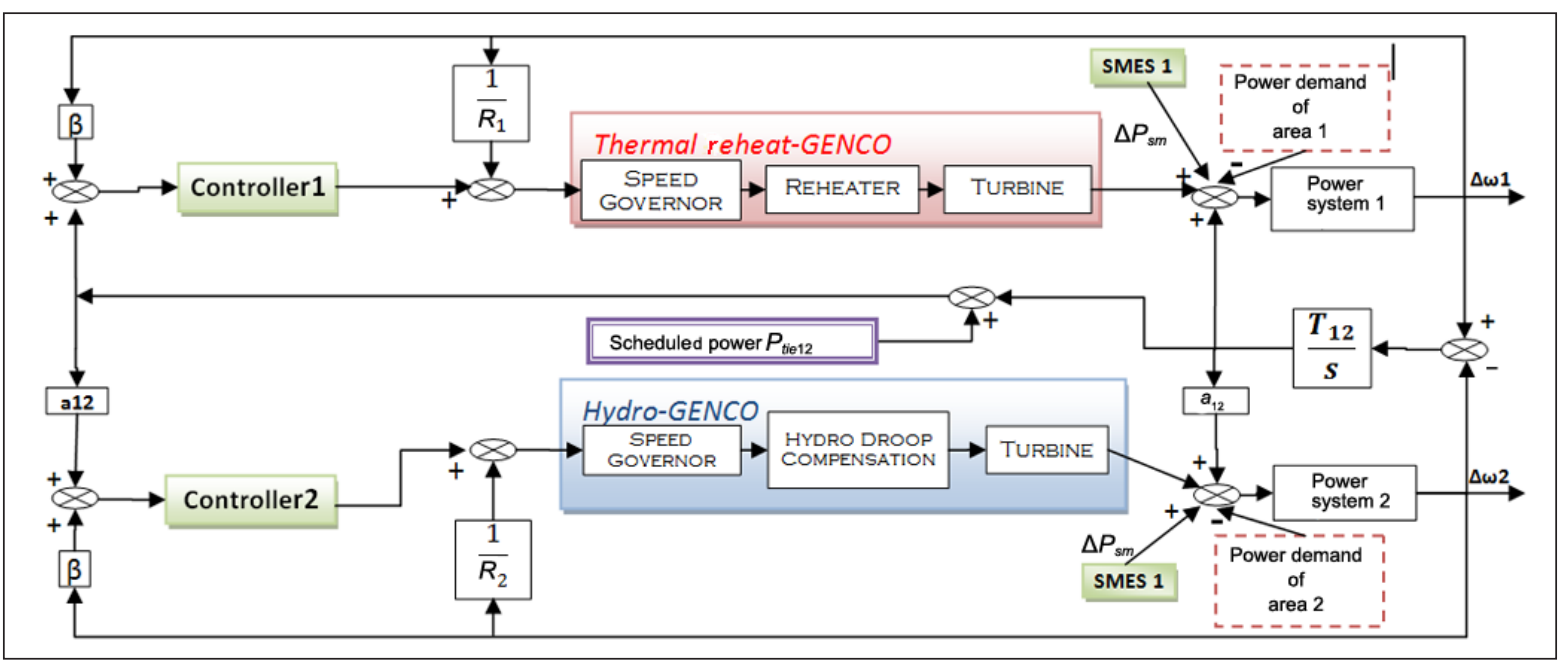

Fig. 1. A complete system model of LFC of two-area thermal-hydro power system 
(ii) All control areas should be controllable to the frequency control.

In LFC, the difference between actual generation and scheduled generation is termed as the area control error (ACE) for the interconnected power system[10]:

$$
\mathrm{ACE}_{i}=\Delta P_{t i e, i j} \beta_{i} \Delta_{\rho}
$$

where $\beta_{i}$ is the frequency bias constant, $\Delta_{f}$ is the frequency deviation, and $\Delta P_{t i e, i j}$ is the change in the tie-line power flow error between area $i$ and area $j$.

Therefore, the scheduled tie line power flow between area- 1 and area- 2 is as follows:

$$
\Delta P_{t i e 12, s c h}=\Delta P_{\mathrm{L}, \mathrm{A} 1 \rightarrow \mathrm{A} 2}-\Delta P_{\mathrm{L}, \mathrm{A} 2 \rightarrow \mathrm{A} 1},
$$

where $\Delta P_{\mathrm{L}, \mathrm{A} 1 \rightarrow \mathrm{A} 2}$ indicates the tie-line power flow from area-1 to area-2 and $\Delta P_{\mathrm{L}, \mathrm{A} 2 \rightarrow \mathrm{A} 1}$ indicates the tie-line power flow from area-2 to area-1.

\section{Superconducting magnetic energy storage}

SMES as an energy storage system can charge and discharge very fast with high quantity of power for a short span of time. The SMES system includes four parts: a superconducting coil, a power conditioning system, a refrigeration system and a control unit. The power conditioning system is with an inverter / rectifier circuit for conversion of AC to DC and vice versa. Charging and discharging of SMES occur through the power conditioning system [11]. The refrigeration system maintains a superconducting coil below the critical temperature. The control unit is only responsible for the mode of operation. Operating mode selection is done by a controller. In the system under test, the error signal, i. e. the area control error (ACE), is fed as an input signal to the SMES control unit. SMES operates in three modes of operation: these are charging, discharging, and charge sustain modes. During the charging mode, the superconducting coil is charged to a set value of charge from the utility grid. In the discharging mode, the stored energy is released. Whenever there is a sudden release in the load, then SMES comes to the charging mode and it immediately gets charged to full value. As soon as the system returns to a steady state, SMES returns to the charge sustain mode $[12,13]$.

The ACE signal is sensed by the controller of SMES and it is further processed by the internal circuitry where coil inductance is represented by $L$ through which the initial DC current $I_{s m 0}$ flows while the incremental change in DC current is $\Delta I_{s m} . T$ is the time delay of the convertor in the power conditioning unit which is represented by the first order transfer function and $K_{s m}$ is the feedback gain of the SMES unit. $\Delta V_{s m}$ is an incremental change in the SMES voltage and finally $\Delta P_{s m}$, the incremental change in the SMES unit power corresponding to ACE, is received at the power junction in the interconnected system. A mathematical model of the SMES unit is shown in Fig. 2 and the parameter values are given in the Appendix.

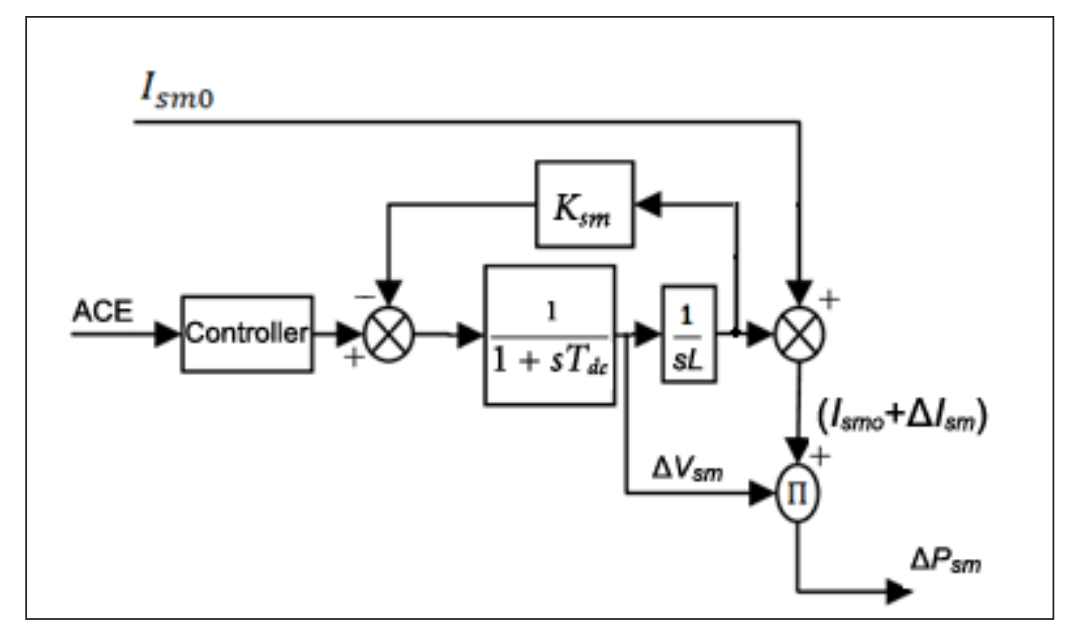

Fig. 2. A mathematical model of the SMES unit 


\section{CONTROL STRATEGIES FOR FREQUENCY CONTROL}

Frequency control being a critical issue in the modern day power system requires a solution with emphasis on intelligence, robustness, and stability. The paper discusses intelligent techniques for control action as well as optimization in the form of fuzzy logic and genetic algorithm, respectively, to obtain an optimal solution to address frequency and tie-line oscillation suppression. Broadly, the methods used are categorized in two domains: the first one is the conventional PID controller and the second one is the fuzzy logic controller. Both approaches have been discussed in detail in the following sections.

\section{Conventional PID controller}

From past few decades the PID controller is one of favourable choices for engineers in the power system. The PID controller selected for LFC has $\mathrm{ACE}_{i}$ as a controller input and $U_{\text {pid }}$ as an output. The expression in (3) depicts the relationship between parameters:

$$
U_{p i d}=K_{p}\left[(\mathrm{ACE}]_{i}\right)+K_{i}\left(\int \mathrm{ACE}_{i} d t\right)+K_{d}\left(\frac{d \mathrm{ACE}_{i}}{d t}\right)
$$

In the PID control scheme, controller's parameters, i. e. $K_{p}, K_{i}$ and $K_{d^{\prime}}$ are obtained from two different methods, where the first one is the Zigler Nicholas tuning method and the second one is GA optimization. The details of tuning and optimization methods used for selection of gain parameters are given below:

\section{Zigler Nicholas tuning}

The Zigler-Nicholas ( $\mathrm{ZN}$ ) tuning method is a heuristic approach for the PID controller. This method is based on the selection of proportional gain to get sustained oscillation, from which ultimate gain $K_{u}$ and oscillation period $T_{u}$ are obtained [14]. PID controller parameters, i. e. $K_{p}, K_{i}$ and $K_{d}$ are calculated from the formulas as shown in Table 1.

\section{Genetic algorithm}

GA is a stochastic search / optimization algorithm based on a natural genetics mechanism, capable of finding optimal solutions. GA simulates a na-
Table 1. PID controller gains from the ZN tuning method

\begin{tabular}{ccccc}
\hline & ZN tuned PID & Area-1 PID gains & Area-2 PID gains \\
\hline $\boldsymbol{K}_{\boldsymbol{p}}$ & $0.6 K_{u}$ & 1.074 & 1.074 \\
\hline $\boldsymbol{K}_{\boldsymbol{i}}$ & $2 K_{p} / T_{u}$ & 0.74 & 0.74 \\
\hline $\boldsymbol{K}_{\boldsymbol{d}}$ & $K_{p} T_{u} / 8$ & 0.389 & 0.389 \\
\hline
\end{tabular}

tural selection and evolution process and is recognized as an effective and efficient technique to solve optimization problems of different fields of engineering. GA is based on three genetic operators: Reproduction, Crossover, and Mutation.

The application of these three basic operations allows the creation of new individuals which may be better than their parents. The process is often repeated until it converges, i. e. when the final population's individual represents the optimum solution to the problem. During this entire process the population size will be maintained. Individuals in a population are coded as the fixed length of string that is analogous to the chromosome, which actually encodes values for variables. Each individual represents a possible solution of the defined problem within a search space $[15,16]$. The GA optimization process is explained in the flow chart as shown in Fig. 3.

\section{Objective function}

Selecting the objective function for any optimization tool is a vital step. Through the objective function each individual's fitness value is evaluated in a population. The objective function for PID optimization is based on the minimization of the Integral of the Absolute Error (IAE) given in (4):

$$
U_{p i d}=K_{p}\left[\left(\mathrm{ACE}_{i}\right)+K_{i}\left(\int \mathrm{ACE}_{i} d t\right)+K_{d}\left(\frac{d \mathrm{ACE}_{i}}{d t}\right),(4)\right.
$$

where $T$ is selected as 30 seconds for the present system. The fitness value is inversely proportional to IAE for the individual, and the higher the value of IAE the smaller the fitness value and vice versa. GA optimized PID gains obtained are shown in Table 2.

$$
\text { Fitness value }=\frac{1}{J_{\mathrm{IAE}}} .
$$




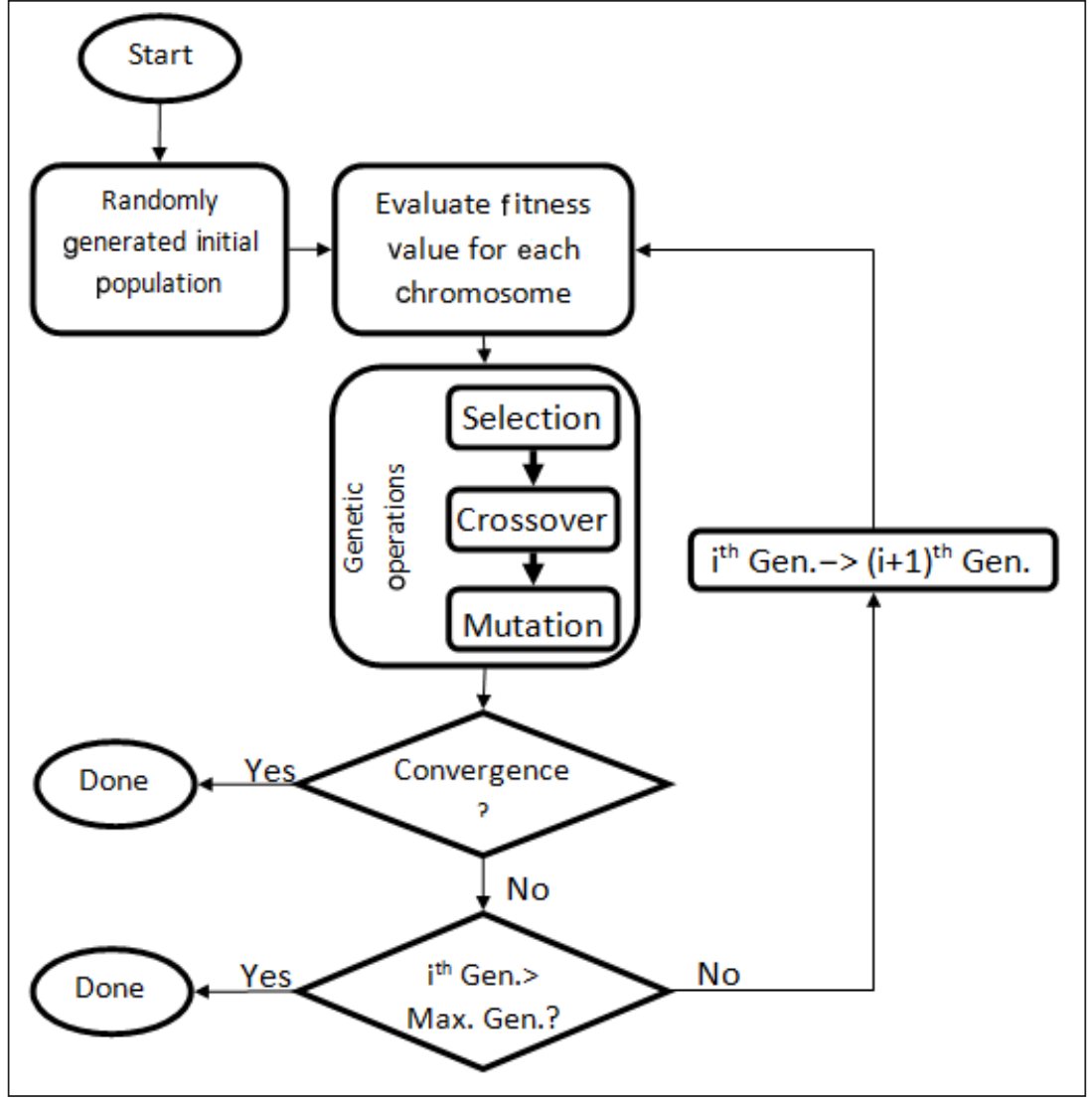

Fig. 3. GA flow chart

Table 2. PID controller gains from the GA optimization method

\begin{tabular}{|c|c|c|c|c|}
\hline $\begin{array}{l}\text { S. } \\
\text { N. }\end{array}$ & & & $\begin{array}{l}\text { Area-1 PID } \\
\text { gains }\end{array}$ & $\begin{array}{c}\text { Area-2 PID } \\
\text { gains }\end{array}$ \\
\hline \multirow{3}{*}{1.} & \multirow{3}{*}{$\begin{array}{c}\text { GA optimized } \\
\text { PID controller } \\
\text { gains }\end{array}$} & $K_{p}$ & 1.6823 & 0.770119 \\
\hline & & $K_{i}$ & 1.44188 & 0.891877 \\
\hline & & $K_{d}$ & 0.66441 & 0.165158 \\
\hline
\end{tabular}

\section{OPTIMIZED FUZZY LOGIC CONTROLLER}

In the last few years the use of fuzzy logic in the solution for control problems has abruptly increased due to its effectiveness over a non-linear or a complex system in comparison to conventional controllers. The fuzzy logic system is a rule based logical controller, in which its rule and parameters are tuned with experimentation or experience. But in a complex system sometimes the designer of the controller may not be able to tune it perfectly and it may lead to per- formance degradation. Therefore, an optimization method is desired to perfectly tune FLC for optimum performance.

The FLC modeling consists of three steps, i. e. fuzzification, formation of fuzzy control rule base and defuzzification. Control actions of an FLC are described by sets of linguistic rules. Dual input and single output type FLCs are designed for LFC. These two inputs are $\mathrm{ACE}_{i}$ and $d \mathrm{ACE}_{i} / d t$ and one output is $U_{i}$ for each control area, as shown in Fig. 4. The Mamdani type fuzzy logic design is used for the FLC design as given in $[17,18]$. Three

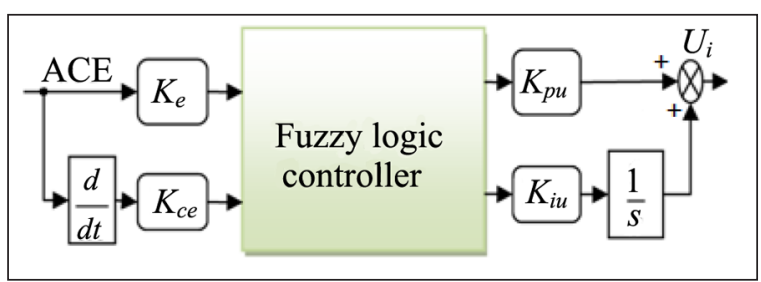

Fig. 4. Fuzzy logic controller for LFC 
triangular type and two trapezoidal type membership functions are considered for both inputs as well as for a single output. The distribution of membership functions on the complete range is shown in Fig. 5.

Table 3 presents the view of rules for FLC utilized to design the controller. In the rule base 25 rules are designed to get the desired response. There are two scaling factors $\left(K_{e}\right.$ and $\left.K_{c e}\right)$ for both input variables $\left(\mathrm{ACE}_{1}, d \mathrm{ACE}_{1}\right)$, respectively, and two gain factors $K_{p u}$ and $K_{i u}$ as proportional and integral gains, respectively.

\section{Table 3. Rule base for FLC controller}

\begin{tabular}{c|cccccc}
\hline & \multicolumn{6}{|c}{$\Delta$ ACE } \\
\hline \multirow{1}{*}{$\Psi$} & & VN & SN & Z & SP & VP \\
\cline { 2 - 7 } & VN & VN & VN & SN & SN & Z \\
\cline { 2 - 7 } & SN & VN & SN & SN & Z & SP \\
\cline { 2 - 7 } & $\mathbf{Z}$ & SN & SN & Z & SP & SP \\
\cline { 2 - 7 } & SP & SN & Z & SP & SP & VP \\
\hline VP & Z & SP & SP & VP & VP
\end{tabular}

FLC for the proposed application is optimized in two modes. In the partial optimization process, only two stages are optimized in sequence starting with the ranges of input-output and then the parameters of membership function keeping the same cost function as given in [4]. In the case of complete optimization, two more steps are included in sequence where the rule base and the rule weight are optimized. The system is simulated and results are recorded for both cases of the partial and the fully optimized controller to understand and justify additional steps in the optimization process. The process and sequencing is shown in Fig. 6.

After scaling factors optimization, the optimum values of scaling and gain parameters are shown in Table 4.

Table 4. Optimum value of scaling and gain parameters

\begin{tabular}{c|c|c|c|c}
\hline & \multicolumn{2}{|c|}{ Scaling parameters } & \multicolumn{2}{c}{ Gain parameters } \\
\cline { 2 - 5 } & $\boldsymbol{K}_{\boldsymbol{e}}$ & $\boldsymbol{K}_{c e}$ & $\boldsymbol{K}_{p u}$ & $\boldsymbol{K}_{i u}$ \\
\hline FLC for area-1 & 2.463 & 2.296 & 1.792 & 1.982 \\
\hline FLC for area-2 & 1.784 & 0.111 & 0.066 & 0.546 \\
\hline
\end{tabular}

\section{RESULTS AND DISCUSSIONS}

The simulation results are compiled in a comprehensive way and are presented in a graphical as well as a tabular form. The proposed approach for complete optimization of FLC is executed in four steps using GA, the best fitness found after every iteration in these steps is shown in Figs. 7, 8, 9 and

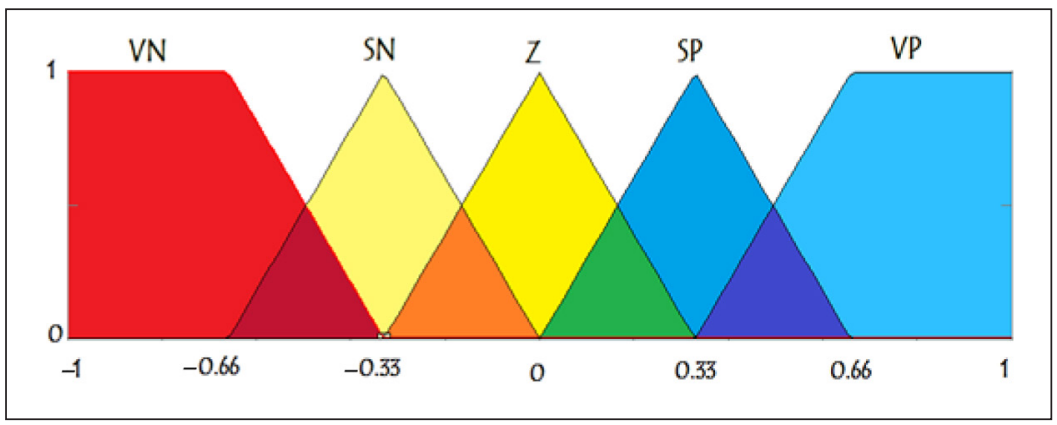

Fig. 5. Membership functions for input and output variables

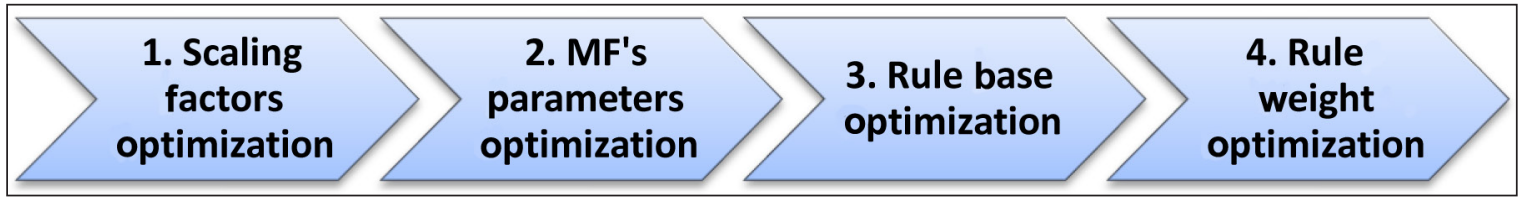

Fig. 6. Optimization process of fully optimized fuzzy logic controller 


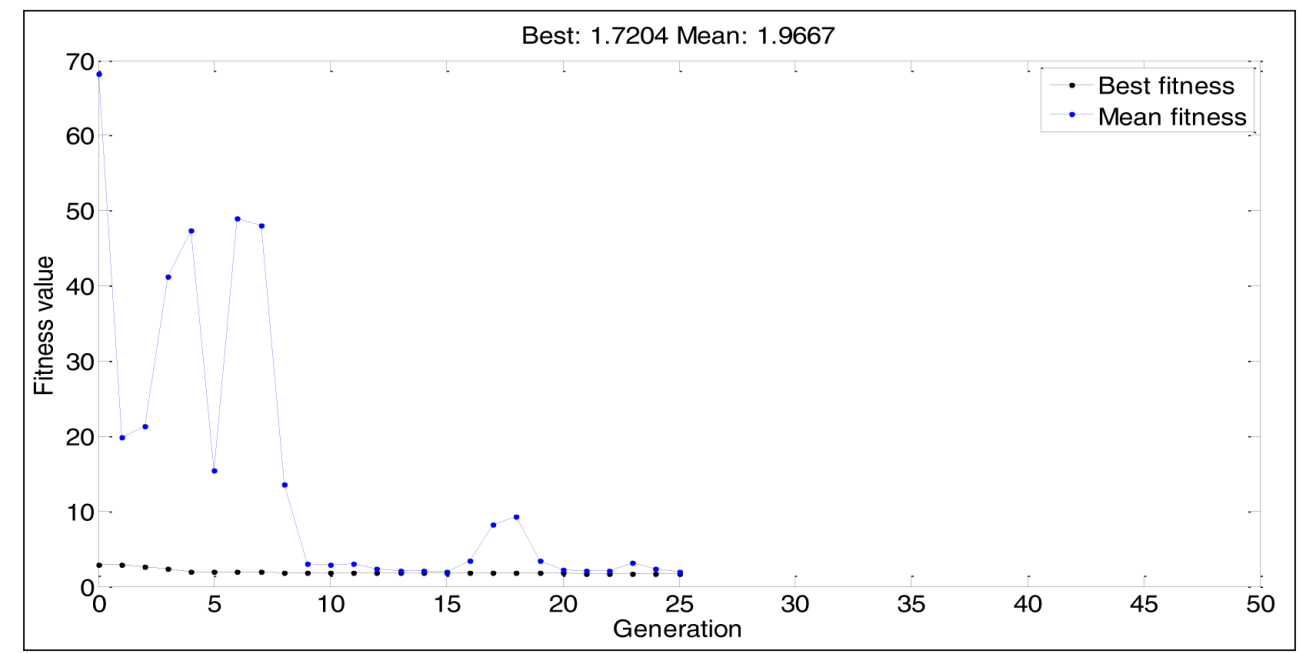

Fig. 7. GA optimization for the scaling factor of FLC

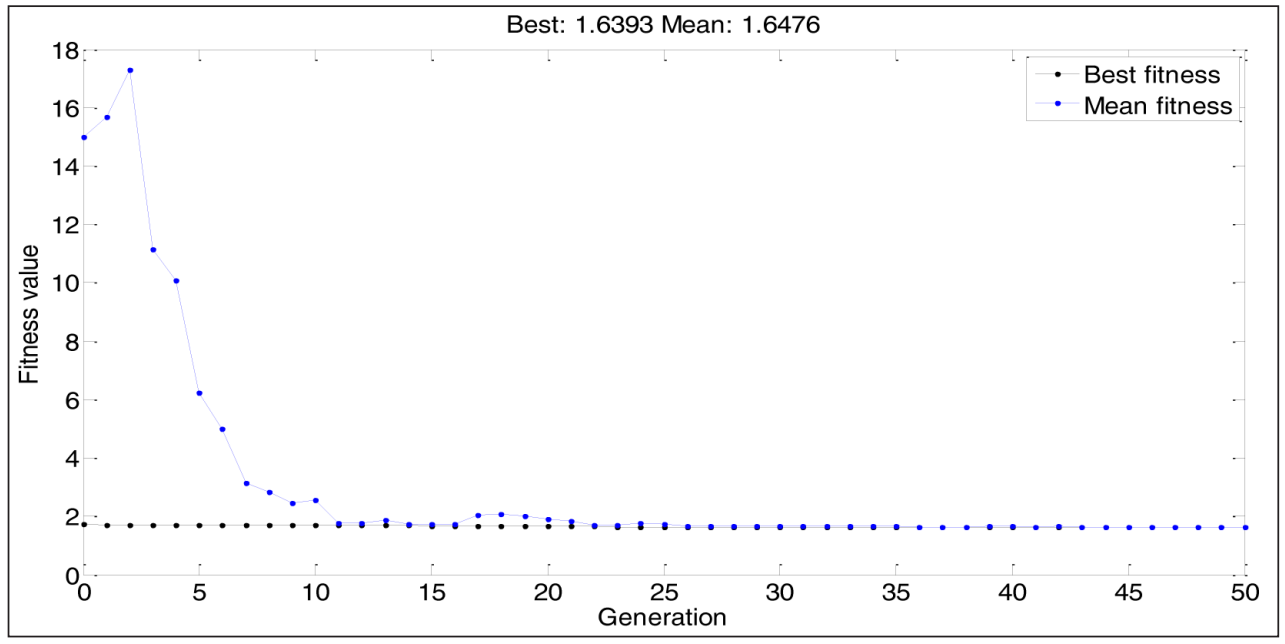

Fig. 8. GA optimization of MF's parameters of FLC

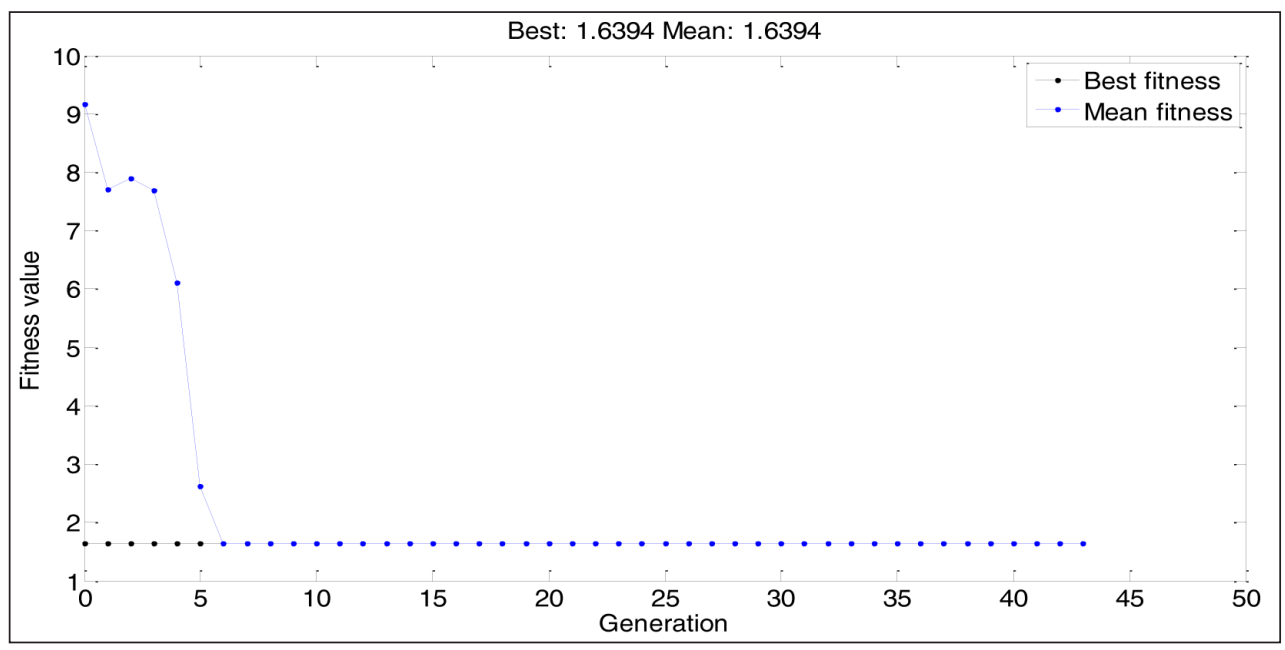

Fig. 9. GA optimization for the rule base of FLC 
10, respectively. The first step is an optimization for the scaling factor whose plot between the fitness value and iteration is shown in Fig. 7. The best fitness value found is 1.7204 while in the second step it is 1.6393 as shown in Fig. 8. This step is for parameter optimization of the membership function. The third step is for optimization of the rule base and shows 1.6394 as the best fitness value given in Fig. 9. The last and fourth step is for the rules weighting factor converged at 1.5901 as shown in Fig. 10.

The dynamic performance of the proposed controller is compared with the ZN tuned PID, GA optimized PID and partially optimized FLC. Two performance indices, peak undershoot and settling time, are considered for the measure to compare the performance of the controller.
Frequency deviations in both areas and tie line deviation after a sudden load change (0.01 p. u.) in each area are shown in Fig. 11. This clearly indicates that frequency deviations in area- 1 and area- 2 from the proposed controller settle faster and a peak undershoot in frequencies is lesser. Table 5 shows the numerical values of performance indices showing that the GA based fully optimized FLC is more effective to damp out oscillations. The proposed controller is $33.4 \%$ effective to reduce the maximum dip in area-1 frequency deviation as well as $61.9 \%$ effective in reducing the settling time in comparison to the conventional controller. On the other hand, it has been observed that in area- 2 it is $24.6 \%$ and $60.9 \%$ better in terms of reduction in the peak undershoot and the settling time, respectively.

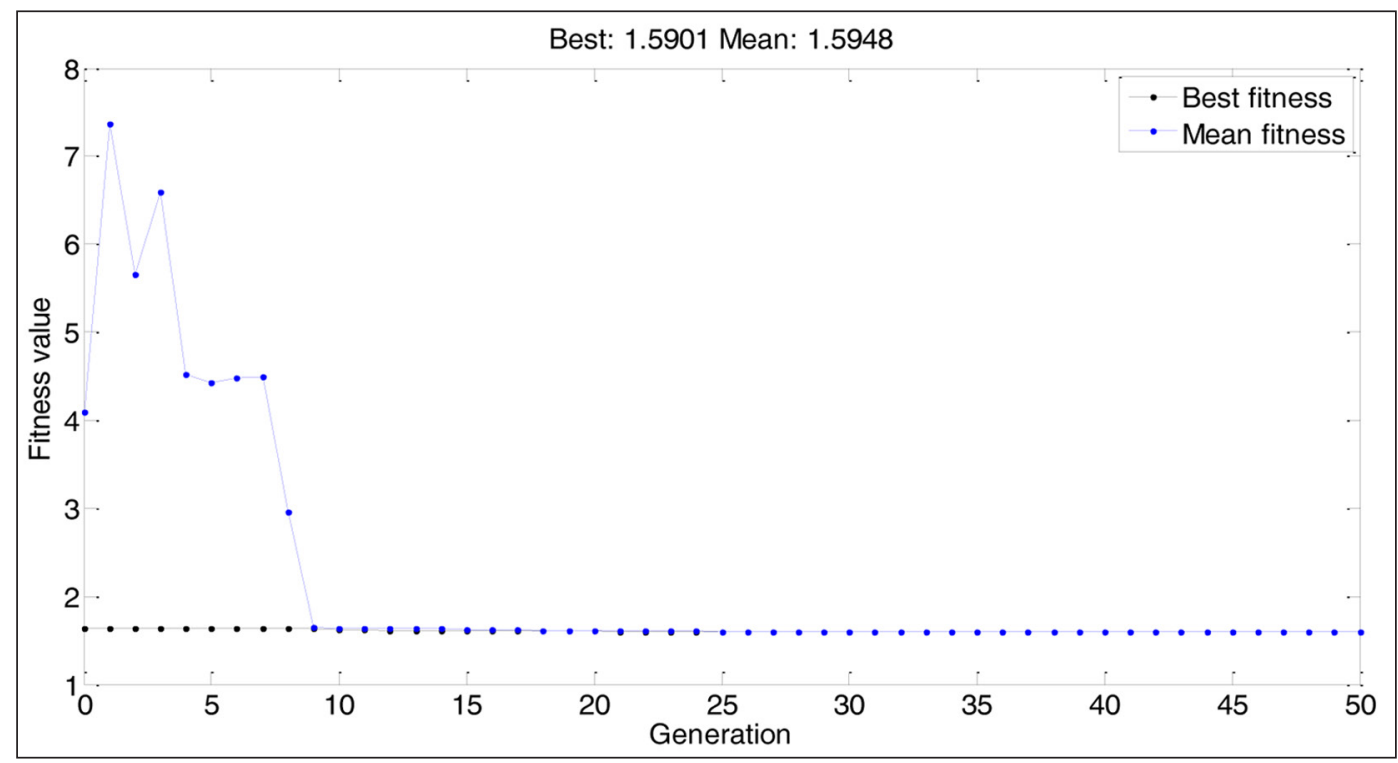

Fig. 10. GA optimization for the rules weighting factor of $\mathrm{FLC}$

Table 5. Comparison of performance indices of $\Delta \mathrm{f} 1, \Delta \mathrm{f} 2$ and $\Delta P_{\text {tie12 }}$ for different control strategies

\begin{tabular}{ccc|ccccc}
\hline & & $\begin{array}{c}\text { ZN tuned PID } \\
\text { controller } \\
\text { without } \\
\text { SMES }\end{array}$ & $\begin{array}{c}\text { GA optimized } \\
\text { PID controller } \\
\text { without SMES }\end{array}$ & $\begin{array}{c}\text { GA based } \\
\text { partially } \\
\text { optimized FLC } \\
\text { without SMES }\end{array}$ & $\begin{array}{c}\text { GA based ful- } \\
\text { ly optimized } \\
\text { FLC without } \\
\text { SMES }\end{array}$ & $\begin{array}{c}\text { GA based fully } \\
\text { optimized FLC } \\
\text { with SMES }\end{array}$ \\
\hline \multirow{2}{*}{$\begin{array}{c}\text { Peak } \\
\text { undershoot }\end{array}$} & Frequency of area-1 & 0.058541 & 0.053201 & 0.039216 & 0.038982 & 0.004596 \\
\cline { 2 - 7 } & Frequency of area-2 & 0.068018 & 0.064058 & 0.051348 & 0.051284 & 0.008396 \\
\cline { 2 - 7 } Settling & Tie-line power & 0.003592 & 0.001806 & 0.003705 & 0.004192 & 0.000061 \\
\cline { 2 - 7 } time $( \pm 5 \%)$ & Frequency of area-1 & 42.799698 & 22.262673 & 16.616575 & 16.305584 & 6.722792 \\
\cline { 2 - 7 } & Frequency of area-2 & 40.301705 & 21.305733 & 15.934718 & 15.745766 & 5.853890 \\
\hline
\end{tabular}



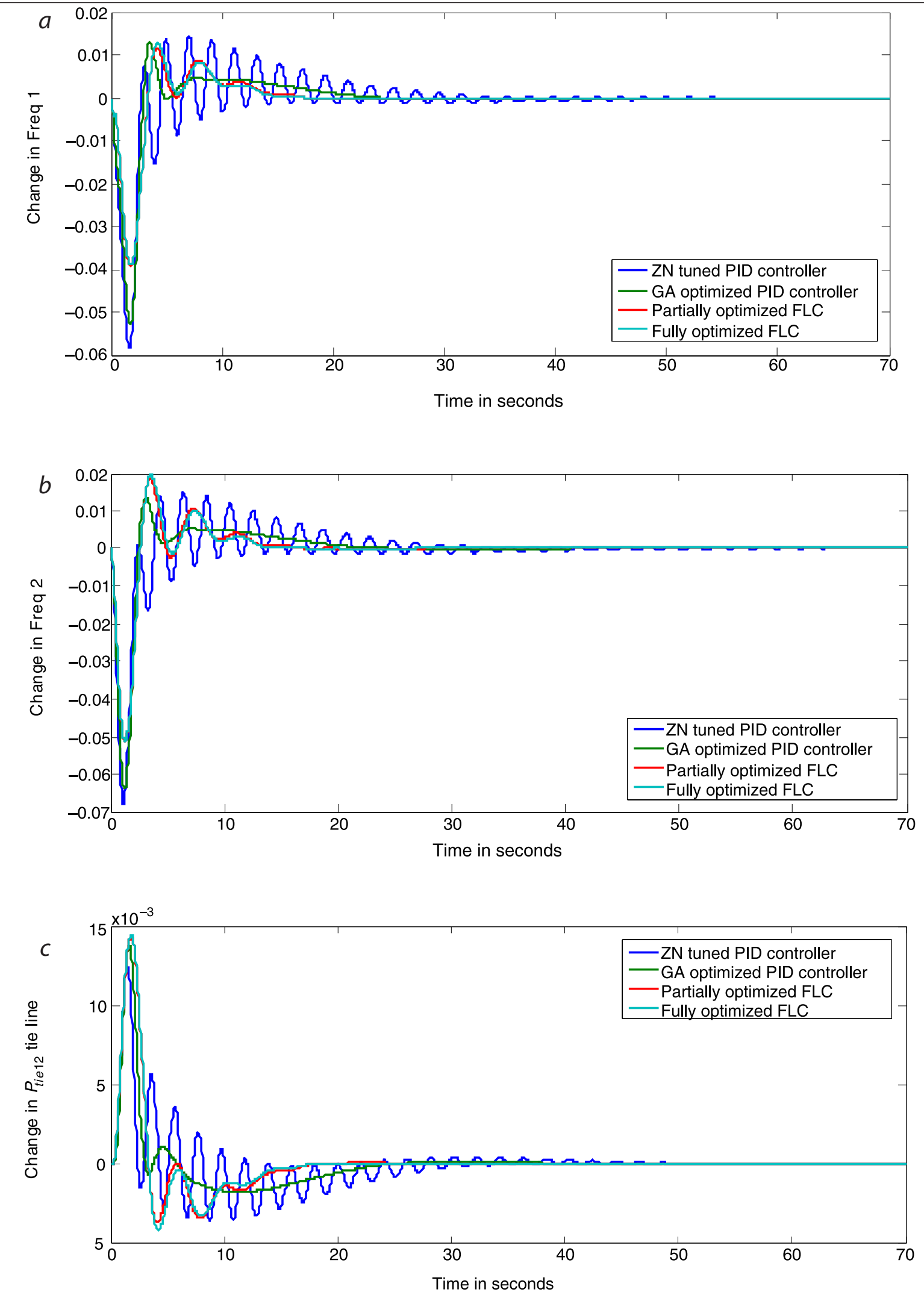

Fig. 11. Comparison of ZN tuned PID, GA optimized PID, partially optimized FLC and fully optimized FLC for two-area thermal-hydro power system (a) $\Delta \mathrm{f} 1,(b) \Delta \mathrm{f} 2,(c) \Delta P_{\text {tie12 }}$ 
In order to effectively minimize frequency and tie-line deviations, use of SMES short-term active power support is also examined with the proposed controller as shown in Fig. 12. The proposed controller with the SMES support reduces peak undershoot in (i) area-1 frequency deviation, (ii) area-2 frequency deviation, and (iii) tie-line power deviation by $92.1 \%, 87.7 \%$ and $98.3 \%$, respectively, and for the settling time this comes as $84.3 \%, 85.5 \%$ and $87 \%$, respectively, when compared with the conventional controller without the SMES support.

The statistical analysis of different controllers in comparison to the conventional controller is shown in Table 6 as well. The test system is considered to

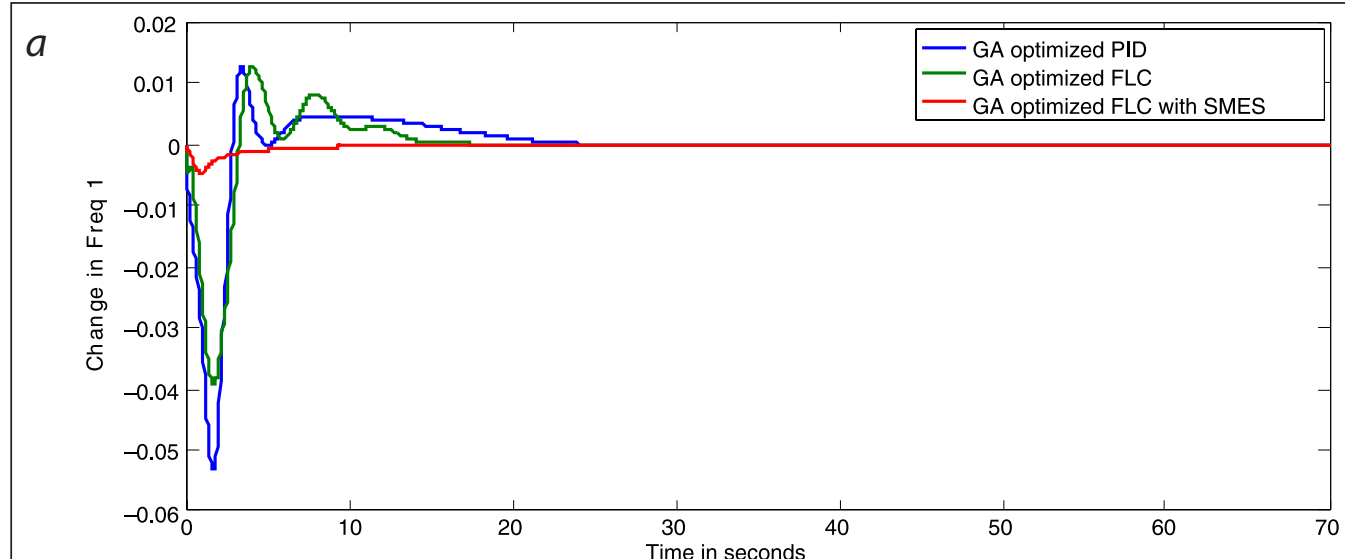

$b$
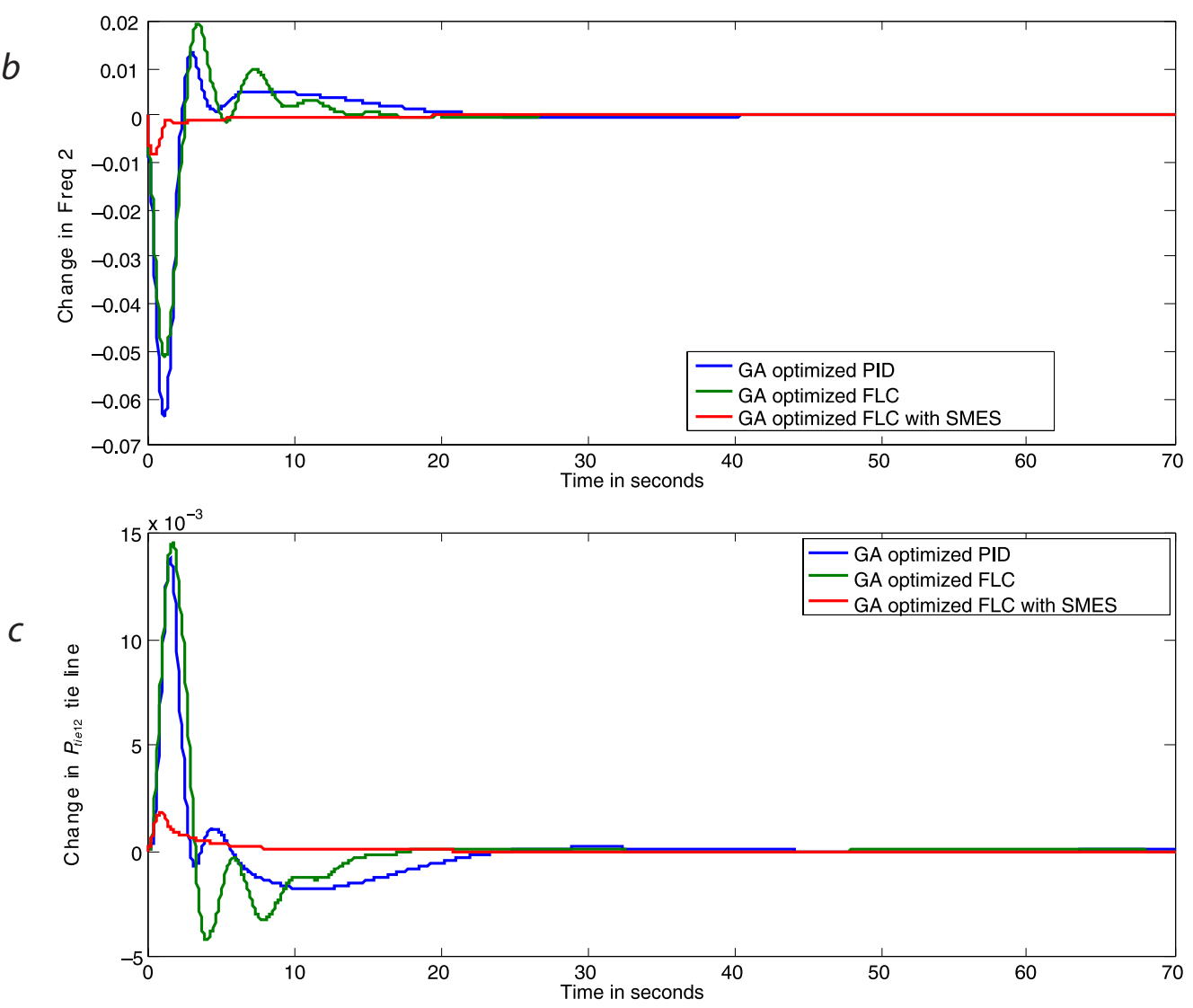

Fig. 12. Comparison of LFC with GA optimized PID, GA optimized FLC and GA optimized FLC with SMES support (a) $\Delta f 1,(b) \Delta f 2,(c) \Delta P_{\text {tie12 }}$ 
Table 6. Statistical analysis of performance indices for different control strategies in comparison to ZN tuned PID controller without SMES

\begin{tabular}{|c|c|c|c|c|c|}
\hline & & $\begin{array}{l}\text { GA optimized } \\
\text { PID controller } \\
\text { without SMES }\end{array}$ & $\begin{array}{c}\text { GA based } \\
\text { partially } \\
\text { optimized FLC } \\
\text { without SMES }\end{array}$ & $\begin{array}{l}\text { GA based fully } \\
\text { optimized FLC } \\
\text { without SMES }\end{array}$ & $\begin{array}{l}\text { GA based fully } \\
\text { optimized FLC } \\
\text { with SMES }\end{array}$ \\
\hline & & \multicolumn{4}{|c|}{ Compared with ZN tuned PID controller without SMES } \\
\hline \multirow{3}{*}{$\begin{array}{l}\text { Peak } \\
\text { under- } \\
\text { shoot }\end{array}$} & Frequency of area-1 & $9.1 \%$ lesser & $33.0 \%$ lesser & $33.4 \%$ lesser & $92.1 \%$ lesser \\
\hline & Frequency of area-2 & $5.8 \%$ lesser & $24.5 \%$ lesser & $24.6 \%$ lesser & $87.7 \%$ lesser \\
\hline & Tie-line power & $49.7 \%$ lesser & $3.1 \%$ more & $16.7 \%$ more & $98.3 \%$ lesser \\
\hline \multirow{3}{*}{$\begin{array}{l}\text { Settling } \\
\text { time } \\
( \pm 5 \%)\end{array}$} & Frequency of area-1 & $48.0 \%$ lesser & $61.2 \%$ lesser & $61.9 \%$ lesser & $84.3 \%$ lesser \\
\hline & Frequency of area-2 & $47.1 \%$ lesser & $60.5 \%$ lesser & $60.9 \%$ lesser & $85.5 \%$ lesser \\
\hline & Tie-line power & $25.6 \%$ lesser & $47.4 \%$ lesser & $49.8 \%$ lesser & $87.0 \%$ lesser \\
\hline
\end{tabular}

be linear and the proposed controller may have limitations when the non-linear system is added but fuzzy logic capability can easily resolve such cases.

\section{CONCLUSIONS}

In the present day situation, power engineers are pressed to deliver quality power to consumers. This paper has attempted to provide a solution in view of the major quality parameter, i. e. frequency fluctuations which pop up during load perturbations in the interconnected system. A comprehensive solution is presented for this load frequency control problem. The paper presents methods and simulated results for different techniques which cover the conventional technique (Zigler Nicholas) to the proposed multi-stage optimized fuzzy logic. Optimization in all processes is also carried out by a genetic algorithm. Results justify that the proposed optimized FLC provides a better performance compared to the ZN tuned PID controller, GA optimized PID and partially optimized FLC. Another source added in the interconnected system is an energy storage device, SMES, which has a unique feature of supporting active power to withstand heavy load disturbances. In the smart grid scenario, SMES has an important role to play in days to come. The controller is also tested with SMES in place in the system and appreciable results are obtained. $88.2 \%$ improvement in the peak undershoot is noted in the area- 1 frequency change with SMES and without SMES despite the fact that disturbance is given in area- 1 only. Similarly settling time improvement is $58.75 \%$.
Other results also strengthen the justification of implementing the optimized intelligent controller for frequency stabiliza tion in order to meet the quality power demand. It may be concluded that the proposed controller is able to achieve the desired performance in the present day power system scenario.

\section{APPENDIX:}

Mathematical modelling of LFC

Hydro turbine: $\quad \frac{\left(1-s T_{w}\right)}{\left(1+0.5 s T_{w}\right)}$

Hydro droop compensation:

Speed governor:

Thermal reheater: $\quad \frac{[(1+K])_{r} s T_{r}}{\left(1+s T_{r}\right)}$

Thermal turbine:

Power system: $\quad \frac{K_{p}}{\left(1+s T_{p}\right)}$

Parameters of the Thermal-Hydro System investigated:

\begin{tabular}{lcc}
\hline $\begin{array}{l}\text { Rated power } \\
\text { (area-1 and area-2) }\end{array}$ & $P_{r 1^{\prime}} P_{r 2}$ & $2000 \mathrm{MW}$ \\
\hline $\begin{array}{l}\text { Transfer function gain of } \\
\text { generator (area-1 and area-2) }\end{array}$ & $K_{p 1^{\prime}} K_{p 2}$ & 120 \\
\hline $\begin{array}{l}\text { Generator's time constant } \\
\text { (area-1 and area-2) }\end{array}$ & $T_{p 1^{\prime}} T_{p 2}$ & 20 \\
\hline Governor's time constant & $T_{g 1}$ & 0.08 \\
\hline $\begin{array}{l}\text { Governor's time constant } \\
T_{g 2}\end{array}$ & 0.02 \\
\hline $\begin{array}{l}\text { Hydro droop compensation, } \\
\text { reset time }\end{array}$ & $T_{r}$ & 5 \\
\hline
\end{tabular}




\begin{tabular}{lcc}
\hline $\begin{array}{l}\text { Hydro droop compensation, } \\
\text { temporary droop }\end{array}$ & $R_{t}$ & 0.38 \\
\hline $\begin{array}{l}\text { Hydro droop compensation, } \\
\text { permanent droop }\end{array}$ & $R_{p}$ & 0.05 \\
\hline Hydro turbine's time constant & $T_{w}$ & 1 \\
\hline Steam turbine's time constant & $T_{t}$ & 0.3 \\
\hline $\begin{array}{l}\text { Regulation of the governor } \\
\text { (area-1 and area-2) }\end{array}$ & $R_{1^{\prime}} R_{2}$ & 2.4 \\
\hline $\begin{array}{l}\text { Frequency bias constant } \\
\text { Synchronizing power }\end{array}$ & $\beta$ & 0.425 \\
\hline coefficient & $a_{12}$ & 1 \\
\hline Synchronization coefficient & $T_{12}$ & 0.545 \\
\hline
\end{tabular}

Received 1 July 2014 Accepted 22 September 2014

\section{References}

1. Wu D., Chau K. T., Member S., Liu C., Gao S., Li F. Transient Stability Analysis of SMES for Smart Grid with Vehicle-to-Grid Operation. IEEE Transactions on Applied Superconductivity. 2012. Vol. 22(3).

2. Jin J. X., Chen X. Y. Study on the SMES application solutions for smart grid. Physics Procedia. 2012. Vol. 36. P. 902-907.

3. Manfredi S., Pagano M., Raimo R. Ultracapacitor-based distributed energy resources to support time-varying smart-grid power flows. Proceedings of International Symposium on Power Electronics, Electrical Drives, Automation and Motion, June 2012. P. 1148-1153.

4. Cam E., Kocaarslan I. Load frequency control in two area power systems using fuzzy logic controller. Energy Conversion and Management. 2005. Vol. 46. P. 233-243.

5. Mathur H., Manjunath H. Frequency stabilization using fuzzy logic based controller for multi-area power system. The South Pacific Journal of Natural Sciences. 2007. Vol. 4. P. 22-30.

6. Chown G., Hartman R. Design and experience with a fuzzy logic controller for automatic generation control (AGC). IEEE Transactions on Power Systems. 1998. Vol. 13(3). P. 965-970.

7. Hemmati R., Mojtaba S., Boroujeni S., Delafkar H., Boroujeni A. S. Fuzzy load frequency control in multi area electric power system. Indian Journal of Science and Technology. 2011. Vol. 4(7). P. 796-800.

8. Tripathy S., Bak-Jensen B. Automatic generation control of multi-area power system with superconducting magnetic storage unit. 2001 IEEE Porto Power Tech Proceedings. P. 250-255.

9. Demirören A., Zeynelgil H. L., Sengor N. S. Automatic generation control for power system with SMES by using neural network controller. Electric Power Components and Systems. 2003. Vol. 31(1). P. 1-25.

10. Kundur P. Power System Stability and Control. New York: McGraw-Hill, 2006. P. 739.

11. Arsoy A. B., Member S., Wang Z. Transient modeling and simulation of a SMES coil and the power electronics interface. IEEE Transactions on Applied Superconductivity. 1999. Vol. 9(4). P. 4715-4724.

12. Tripathy S. C. Sampled data automatic generation control with superconducting magnetic energy storage in power systems. IEEE Transactions on Energy Conversions. 1997. Vol. 12(2). P. 187-192.

13. Sheikh M., Muyeen S., Takahashi R., Murata T., Tamura J. Improvement of load frequency control with fuzzy gain scheduled SMES unit considering governor dead-band and GRC. Proceedings of 5th International Conference on Electrical and Computer Engineering, December 2008, Dhaka, Bangladesh. P. 1-6.

14. Ziegler J. G., Nichols N. B. Optimum settings for automatic controllers. Transactions of the ASME. 1942. Vol. 65(5). P. 433-444.

15. Goldberg D. E. Genetic Algorithms in Search, Optimization and Machine Learning. Boston: Addison-Wesley Professional, 1989. 432 p.

16. Bhongade S., Gupta H., Tyagi B. Genetic algorithm based PID controller for frequency regulation ancillary services. International Journal of Engineering Science and Technology. 2010. Vol. 2(12). P. 6902-6908.

17. Bhateshvar Y. K., Mathur H. D. Comparative dynamic analysis on frequency stabilization for multi-area power system in deregulated environment. Proceedings of 2012 IEEE International Conference on Signal Processing, Computing and Control (ISPCC). P. 1-6. 
18. Mathur H. D., Leite L. B. F., Siguerdidjane H., Bhateshvar Y. K. Study of impact of wind power penetration on frequency stabilization in multi-area power system. Proceedings of 2013 8th International Symposium on Advanced Topics in Electrical Engineering (ATEE). P. 1-6.

Y. K. Bhateshvar, H. D. Mathur

\section{SISTEMOS SU SUPERLAIDŽIU MAGNETINIU ENERGIJOS KAUPIKLIU GALIOS IR DAŽNIO BALANSAVIMAS NAUDOJANT IŠMANŲJI SISTEMOS OPTIMIZAVIMO VALDIKLI}

\section{Santrauka}

Straipsnyje pateikiamas optimizuotos struktūros Fuzzy loginis valdiklis, skirtas galios ir dažnio nuokrypiams, atsiradusiems dèl apkrovos pokyčių, sureguliuoti elektros energetikos sistemoje iš dviejų posistemių. Viename iš jų modeliuojamas šiluminès elektrinès generatorius, kitame - tokios pačios galios hidrogeneratorius. I sistemos modeli įtrauktas superlaidus magnetinis energijos kaupiklis, galintis kaupti energiją ir grąžinti ją ị sistemą pagal pareikalavimą. Kaupiklis užtikrina trumpalaiki aktyviosios galios balanso palaikymą nagrinèjamoje sistemoje. Siūloma Fuzzy loginio valdiklio veikimo schema iš 4 žingsnių. Pirmame žingsnyje optimizuojama ịvedamų ir išvedamų parametrų diapazonas, antrame - priklausomumo funkcijos, trečiame - taisyklių rinkinys ir ketvirtame - taisyklių svarbumo koeficientai (svoriai). Optimizuojama genetiniu algoritmu. Jị taikant gauti optimalesni rezultatai nei kitais literatūroje pateikiamais metodais. Optimizavimo rezultatai palyginami lentelèse pagal du parametrus - nusistovejimo laiką ir dažnio staigųjị nuokrytị (ang. undershoot).

Raktažodžiai: elektros energetikos sistema iš posistemių, galios-dažnio valdymas, Fuzzy loginis valdiklis, genetinis algoritmas, SMES
И. К. Батешвар, Н. Д. Матур

\section{БАЛАНС АКТИВНОЙ МОЩНОСТИ \\ И ЧАСТОТЫ В ЭНЕРГОСИСТЕМЕ СО \\ СВЕРХПРОВОДЯЩИМ МАГНИТНЫМ \\ НАКОПИТЕЛЕМ ЭНЕРГИИ С ПОМОЩЬЮ \\ ОПТИМИЗИРОВАННОГО КОНТРОЛЛЕРА НЕЧЕТКОЙ ЛОГИКИ}

\section{Резюме}

Статья представляет оптимизированную структуру контроллера нечеткой логики для регулирования отклонений активной мощности и частоты в энергосистеме, вызванных изменениями нагрузки. Система состоит из двух подсистем, в одной из которых моделируется тепловой генератор, а в другой - гидро генератор. В систему введен сверхпроводящий магнитный накопитель энергии, который может накопленную энергию мгновенно вернуть в систему по востребованию контроллера. Накопитель поддерживает в течение короткого периода времени баланс активной мощности системы. Схема работы предлагаемого контроллера состоит из 4 шагов. На первом шагу оптимизируются диапазоны входных и выходных параметров, на втором - функции зависимости, на третьем - база правил и на четвертом - значимости (весовые коэффициенты) этих правил. В качестве метода оптимизации применен генетический алгоритм, и в итоге получены более оптимальные результаты, чем по другим методам, представленным в литературе. Результаты оптимизации сравниваются по двум параметрам - времени урегулирования и величине максимального недорегулирования частоты (анг. undershoot).

Ключевые слова: контроллер нечеткой логики, генетический алгоритм 